\title{
Pleito por la herencia de Abdallá de Santo Tomé, según «La Ley e Açunna de Moros»*
}

\author{
Abdallá de Santo Tomés inheritance lawsuit according to $L A L E Y$ \\ E AÇUNNA DE MOROS \\ José-Luis Pascual CABrero**
}

\begin{abstract}
RESUMEN
Estudio del proceso mantenido ante la Real Chancillería de Valladolid, en 1492, con motivo del desencuentro producido por el reparto de la herencia del rico mercader abulense Abdallá de Santo Tome, apelando a «la ley e açunna de moros». El documento nos ofrece una interesante visión, tanto de la aplicación por un tribunal cristiano de la Sunna, como de las actividades comerciales que los mudéjares mantenían con Valencia, desde donde traían ricos productos destinados a las élites castellanas.
\end{abstract}

\section{PALABRAS CLAVE}

Mudéjares; Valencia; Sunna; papel de Génova; herencia; Abdallá de Santo Tomé.

\begin{abstract}
This study examines the trial held at the court of the Royal Chancellery of Valladolid in 1492 concerning the conflict regarding the distribution of the inheritance of a rich merchant from Avila, Abdallá de Santo Tomé, according to $\mathrm{La}$ ley e açunna de moros. This legal document provides an interesting view of the application of the Sunna by a Christian tribunal, as well as insight into the commercial activities maintained by the Mudejars with Valencia, from where they brought rich products destined for the Castilian elites.
\end{abstract}

\section{KEY WORDS}

Mudejars, Valencia, Sunna, the role of Genoa, inheritance, Abdallá de Santo Tomé.

* Fecha de recepción del artículo: 2012-12-20. Fecha de aceptación del artículo: 2013-3-4.

** DEA en Historia. UNED.

Este artículo se ha realizado dentro del Proyecto de Investigación «Los mudéjares y moriscos de Castilla (siglos XI-XVI)» (HAR2011-24915) del Plan Nacional de I+D+i (2008-11), dirigido por Ana Echevarría Arsuaga.

Siglas y abreviaturas empleadas: AGS (Archivo General de Simancas); ACSg (Archivo de la Catedral de Segovia); AHPAv. (Archivo Provincial de Ávila); APHSg (Archivo Provincial de Segovia); ARChVa (Archivo de la Real Chancillería de Valladolid); ASIM (Actas del Simposio Internacional de Mudejarismo); CCA (Cámara de Castilla); doc. (documento); DH (Delegación de Hacienda); exp. (expediente); f./ff. 


\section{INTRODUCCIÓN}

El artículo «Partición de herencia entre una familia mudéjar de Medinaceli», realizado en 1982 por María Jesús Viguera ${ }^{1}$, aportó un importante testimonio sobre los aspectos de la cotidianeidad mudéjar al tratar asuntos internos de tipo económico, jurídico, lingüístico o social, además de abrir nuevas perspectivas de estudio que han constituido el germen de nuevos trabajos relacionados con contenidos de carácter privado o familiar. Una nueva e interesante aportación la encontramos en el trabajo más reciente realizado por Olatz Villanueva ${ }^{2}$, en el que estudia un proceso similar, en esta ocasión el correspondiente a una familia de clase media de la aljama de Valladolid, los Alcalde.

En esa línea, nos parece oportuno aportar un nuevo documento que abre otra perspectiva y amplía el conocimiento de la vida privada mudéjar al incluir la relación de bienes que forman parte de una herencia entre una familia mudéjar de la ciudad de Ávila.

De este modo pretendemos en estas páginas centrar la atención acerca de la aplicación de la Sunna ${ }^{3}$, siguiendo la doctrina maliqui ${ }^{4}$, en un proceso que se llevó a cabo en las postrimerías del siglo XV ante el tribunal de la Real Chancillería de Valladolid a petición de una familia mudéjar, con motivo del desencuentro producido por su reparto. Desgraciadamente no hemos podido localizar el testamento que redactara el difunto Adballá, que incluiría una estructura muy similar a la descrita por M. ${ }^{a}$ Jesús Viguera ${ }^{5}$ :

1. Presentación (lugar, fecha y motivo).

2. Relación de personas y sus rangos (de acuerdo a la ley de Moros) ${ }^{6}$.

(folio/folios); leg. (legajo); MP (Mercedes y Privilegios); RCE (Reales Cartas Ejecutorias); RGS (Registro General del Sello).

1 VIGUERA MOLINS, M. ${ }^{\text {a }}$ J.: «Partición de una herencia entre una familia mudéjar de Medinaceli», en Al-Qantara, III, 1982, pp. 73-134.

2 VILLANUEVA ZUBIZARRETA, O.: «La alcallería mudéjar en Valladolid con nombres propios. La familia Alcalde" en, Castilla y el mundo feudal: homenaje al profesor Julio Valdeón. Coord. por María Isabel del Val Valdivieso y Pascual Martínez Sopena, Vol. 2, Valladolid, 2009, pp. 69-86.

${ }^{3}$ De manera general Sunna significa "costumbre», «uso», «tradición». Dice Felipe Maillo que viene a significar, como parte del vocablo sunnat an-Nabi, «la manera de conducirse el Profeta», siendo aplicada cuando la solución de un caso concreto no aparecía formulada en el Corán. Ver MAILLO SALGADO F.; Vocabulario de historia árabe e islámica, ed. Akal, Madrid, 1999, p. 226.

${ }^{4}$ La escuela jurídico-religiosa maliki es la predominante en la España musulmana. Sigue las directrices de Malik ibn Anas (715-795) quién además de utilizar el Corán, como el resto de escuelas, se basa en la Sunna y en el derecho consuetudinario dominante en Medina en tiempos de Mahoma, dando especial importancia a la maslaha, la utilidad general para toda la comunidad musulmana.

${ }^{5}$ VIGUERA MOLINS, M. ${ }^{a}$ J.: op. cit.

${ }^{6}$ Para el estudio del reparto hemos utilizado dos fuentes diferentes: una corresponde a la copia del manuscrito de las Leyes de Moros realizado por Pascual de Gayangos, identificándolo así a partir de ahora y su correspondiente título en numeral romano. En segundo lugar la copia del Archivo General de la Nación de México del Breviario Sunní de Yça Gidellí, identificando cada capítulo con numeral árabe. 
3. Relación de los bienes objeto del reparto.

4. Procedimiento del reparto.

5. Adjudicación a cada heredero de los correspondientes bienes.

6. Constatación de que cada uno ha recibido su parte.

7. Certificación de que se ha hecho por testigos y notario (que suele ser el alfaquí de la respectiva aljama).

El documento que presentamos se conserva en el archivo de esa ChanciIlería, que guarda la documentación producida por la máxima instancia judicial de la Corona de Castilla — tanto de carácter civil como criminal— pronunciadas por los distintos órganos de justicia del reino, proporcionando una completa visión de la historia social de los últimos años del medievo en la Corona de Castilla.

Aunque el volumen registrado en los archivos de la Real Chancillería de Valladolid y, concretamente, el correspondiente a cartas ejecutorias expedidas es numerosísimo - confirmando la leyenda de que la sociedad medieval era irascible y pleiteadora-, las referidas a la minoría mudéjar son muy escasas (no más de una treintena). Hemos de tener en cuenta que los procesos con la justicia eran gravosos, aunque accedían a ella todos los estamentos sociales, facilitando, a los que menos recursos económicos tenían, la asistencia gratuita de un abogado y de un procurador. El tribunal también facilitaba el acceso de testigos, compensando los gastos de viaje y estancia a la sede del tribunal donde se desarrollara el pleito ${ }^{7}$. Al tribunal podían acceder tanto los poderosos nobles como las personas del común, y también tanto los cristianos, como los moros o los judíos, siendo de esa manera universal para todos. Entre los casi 190.000 registros descriptivos, los pleitos civiles contienen la mayor variedad de asuntos, configurándose, como afirma Varona García $^{8}$, entre los más interesantes para el estudio social, ya que en ellos están implicados tanto individuos como instituciones, dignidades y colectividades, además sus causas son muy diversas al tratar asuntos relativos a injurias, agresiones y deudas, siendo los pleitos sobre términos y las querellas sobre bienes las más numerosas porcentualmente. Una parte de ellos está dedicada a asuntos de herencias y sucesiones, a la petición de cuentas a los tutores de tutelas, a mujeres que demandan su herencia o a la reclamación de sus bienes dotales. Es precisamente a estos asuntos a los que dedicaremos nuestro interés en este artículo.

\footnotetext{
7 «[...] que den a cada uno de los dichos testigos, para que vengan a esta nuestra corte, a los que vinieren caualgando a quarenta e çinco maravedis, e a los que venieren a pie treinta e çinco maravedis, e venidos les mandaran tasar e pagar su justo e debido salario que oviere de aver por venida a nuestra corte, e estancia e tornada a sus casas.» Archivo General de Simancas, Registro del Sello de Corte (en adelante AGS-RGS) 149301-259.

${ }^{8}$ VARONA GARCÍA, M.․ㅡ A.: Cartas Ejecutorias de la Real Chancillería de Valladolid (1395-1490), Universidad de Valladolid, Valladolid, 2002.
} 
Muchos investigadores coinciden en opinar que la escasez documental, en este tipo de pleitos, es en buena parte debida a la falta de archivos internos de la comunidad mudéjar, y, en segundo lugar, como ya hemos anotado, a que los procesos eran gravosos. Si a eso añadimos que este tipo de demandas compete al ámbito privado al tratar asuntos internos - lo que nos permite suponer que los pleitos fueran escritos en árabe y se guardaran en los registros de la propia aljama- el resultado sería «la penuria documental» definida en su momento por Ladero Quesada ${ }^{9}$.

En el caso que nos ocupa, la información que aporta el pleito nos ayuda a intentar desmontar el discurso de la irrelevancia de esta «minoría marginada», al describir actividades relacionadas con la identidad del propio grupo, así como los contactos con correligionarios de otros reinos peninsulares, fortaleciendo la idea de la existencia de una élite económica que desarrollaba negocios rentables que les permitían realizar operaciones para aumentar sus bases de poder ${ }^{10}$. La familia mudéjar de los Santo Tomé ejercía una notable influencia en el ámbito de la sociedad abulense, gozando de cierta popularidad en la ciudad, al igual que ocurriera con otras familias como los Caro, los de las Navas o los arevalenses Albeytar, permitiendo a sus miembros gozar de gran prestigio social, económico, político -incluso ante los reyes ${ }^{11}$-, o religioso como en el caso del alfaquí de Segovia Yça Gidelli. Algunas de estas cuestiones las encontramos en el documento que contribuye, al menos parcialmente, a responder a algunos interrogantes planteados y mejorar la visión de conjunto sobre la comunidad mudéjar.

La pertenencia de los Santo Tomé a la élite económica viene dada por sus intensas e interesantes relaciones económico-comerciales ejercidas desde Ávila ${ }^{12}$

9 LADERO QUESADA, M. Á.: «Los mudéjares en la Edad Media», en I ASIM, Teruel, 1981, p. 349.

${ }^{10}$ ECHEVARRÍA ARSUAGA, A.: «Los Caro-Alfageme de Ávila, una familia de alfaquíes y comerciantes de Ávila", en Biografías mudéjares o la experiencia de ser minoría: biografías islámicas en la España cristiana, Ana Echevarria Arsuaga, ed., Estudios Onomásticos-Biográficos de al-Andalus, XV, CSIC, Madrid, 2008.

${ }^{11}$ En 1498 la aljama de Arévalo es requerida a pagar el reparto extraordinario decretado para ese año y la propia aljama pide a Alí Albeytar y a sus hijos que contribuyan con una mayor cantidad de dinero para rebajar la aportación de los mudéjares arevalenses, a lo que los Albeytar se niegan recurriendo a una cédula otorgada por Isabel I: «[...] yo vos mando que pagando Ali Albeytar, moro vesino de la dicha villa de Arevalo, e sus hijos los maravedis que le copieren a pagar de los dichos castellanos, segund el tenor e forma de la dicha carta de rreçeptoria. E non costringades nin apremiedes a pagar mas por via de enprestido nin en otra manera [...] por los serviçios quel dicho Ali Albeytar hiso a la rreyna [en referencia a Isabel de Portugal] mi sennora que Santa Gloria aya.» ARChVa, RCE, 126-27 f. 2 r.

${ }_{12}$ Serafín de Tapia destaca que los musulmanes abulenses sobresalían en las actividades mercantiles, afirmando que "de los 99 vecinos de los que conocemos su oficio a principios del siglo XVI, 32 de ellos eran arrieros o mercaderes", en de Tapia Sánchez, S.: «La opresión fiscal de la minoría morisca en las ciudades castellanas. El caso de Ávila», en Studia Historica. Historia Moderna, N.․ 4, 1986, pp. 17-50. Ver del mismo autor, sobre estas cuestiones, «Las redes comerciales de los moriscos en Castilla la Vieja: un vehículo para sus complicidades", en Studia Historica. Historia Moderna, N.. 10-11, 1992-93, pp. 231-244. Y muy especialmente La Comunidad morisca de Ávila, Universidad de Salamanca, 1991, 
con el Mediterráneo y con otros lugares de la corona de Castilla. Sin duda, esta relación debió llegar a su madurez a través de distintas fases ${ }^{13}$, en las que la convivencia de prácticas antiguas con otras modernas representaría uno de sus rasgos principales que culminaría con la asociación con comerciantes genoveses. Las funciones de puertos y mercados francos, diseminados por la geografía peninsular y fomentados por la Corona para fortalecer el sistema económico, pudo ser la base del extraordinario crecimiento del comercio durante la segunda mitad del siglo $\mathrm{XV}$, estando caracterizado por una fuerte preponderancia de las importaciones sobre las exportaciones y por un comercio vinculado a la industria doméstica, siendo Valencia y Génova, entre otras, dos de las ciudades centrales en el mercado mediterráneo internacional. A pesar de la preponderancia de ese tipo de mercado, el papel y la seda de Xátiva constituyeron una importante fuente de ingresos, que se remonta a la etapa andalusí y se mantiene hasta fines de la Edad Media $^{14}$.

\section{LOS CASOS DE HERENCIA MUSULMANA ${ }^{15}$}

El proceso fue atendido en una de las cuatro salas de lo Civil y presidido por un oidor en «grado de apelación», puesto que ya había sido tratado en primera instancia por la justicia ordinaria ${ }^{16}$. Esto era lo habitual en caso de tratarse de tribunales cristianos; en el caso de los moros castellanos existía una estructura jerárquica que se iniciaba en primera instancia en el consejo de ancianos de la alja-

obra imprescindible para acercarse al conocimiento de la comunidad musulmana abulense en general, y de sus actividades económicas en particular.

${ }_{13} \mathrm{~J}$. Hinojosa Montalvo apunta que la participación mudéjar en las actividades comerciales es una viva herencia de la época musulmana, destacando la vitalidad de las grandes familias de mercaderes de Valencia. Ver Hinojosa Montalvo, J.: Los mudéjares. La voz del Islam en la España Cristiana, II Vols. Teruel, 2002, pp. 220-227 del primer volumen.

14 HINOJOSA MONTALVO, J.: «Balance y perspectivas de los estudios mudéjares en España: 1975-2005", en Actas del X Simposio Internacional de Mudejarismo (en adelante ASIM), Teruel, 2007, p. 78.

${ }^{15}$ Ley de Moros, Título CCLXXXVIII, de los herederos de los onmes que son diez: «Los herederos de los onmes son diez: el fijo, el fijo del fijo; e el padre, e el abuelo. Et el hermano, e el fijo del hermano. Et el hami, e el fijo del hami, e el marido e el sennor. Et los herederos de las mugeres son syete: las fijas e la fija del fijo quando el açediese, e la madre e la abuela, e la hermana, e la muger e la sennora». Ver también, sobre derecho matrimonial, Imam Maliik, Al-Muwatta, Libros 27 y 37 (trad. de Abdurrasak Pérez), Centro de documentación y publicaciones islámicas, Junta Islámica, Córdoba, 1999. También Soha Abboud-Haggar, El Tratado jurídico de al-Tafri de Ibn al-Gallab, manuscrito aljamiado de Almonacid de la Sierra, Ed. Institución «Fernando el Católico», Zaragoza, 1999.

${ }^{16}$ El punto de partida para conocer la articulación de los diferentes recursos procesales del derecho castellano lo constituye el reinado de Alfonso $\mathrm{X}$, al crear un aparato de justicia dirigido a someter la práctica jurídica a la Corona. Ver Partida Tercera, Título XXIII «De las alzadas que facen las partes quando se tienen por agraviados de los juicios que se dan contra ellos" y XXIV "Como los juizios se pueden revocar et oyr de cabo, quando el rey quisiere facer merced a alguna de las partes". Alfonso X, Siete Partidas, edición electrónica de la Universidad de Sevilla, facs. 1804. 
ma, para pasar en grado de apelación al cadí y finalmente, si fuera necesario, al alcalde mayor de todas las aljamas del reino ${ }^{17}$.

Este documento estaría dentro de la categoría definida como «casos de herencia», que resueltos a través del pleito, enfrentaban a distintos familiares por las herencias de los padres, o a los hijos con sus padres que reclamaban su correspondiente parte de herencia al progenitor superviviente. En otros sumarios, se reclamaba el posible disfrute ilícito del cónyuge sobreviviente en perjuicio de herederos legítimos. Otras reclamaciones dentro de la misma tipología, están relacionadas con la demanda de huérfanos —al alcanzar la mayoría de edad- de los bienes; de la parte que pudiera corresponder, como es este caso; o contra los tutores que administraban ese patrimonio ${ }^{18}$. Otros tantos afectan a la Iglesia, que reclama la propiedad de los bienes que le eran dejados en herencia por particulares, a particulares con la iglesia o a bienes intestados de moros.

De la treintena de documentos relacionados con mudéjares que aludíamos, únicamente cinco, incluido el que estudiamos, estarían relacionados con estas cuestiones. Entre ellos destacan los procesos iniciados por la exclusión de la parte correspondiente de la herencia de uno de los herederos por haberse convertido al cristianismo ${ }^{19}$; es el caso de María Álvarez ${ }^{20}$, vecina de Guadalajara, que litiga en 1494 con Alí de Ayllón, moro vecino de Madrid, sobre la posesión de unas casas pertenecientes a la herencia de su padre Hamed Pexias, de la que fue excluida por ser cristiana. Otros tienen que ver con el incumplimiento de dote, como es el iniciado por Ali Albéitar en 1500, en nombre de su hija Fátima, vecinos de Arévalo (Ávila), con Giber Bory, sobre incumplimiento de dote matrimonial por parte del novio ${ }^{21}$; contra la aljama por apropiación de la herencia como, por ejemplo, el pleito litigado por Fabián Sallios, moro vecino de Medinaceli (Soria), con la aljama de los moros de Medinaceli, sobre la devolución de la herencia de Abraham Rojo ${ }^{22}$; o simplemente la reclamación de bienes, como es el pleito litigado por Ali Provecho con Abdalla Provecho y Ali Serrano, moros, vecinos de Plasencia (Cáceres), sobre la herencia de Abraym Serrano ${ }^{23}$, estudiado por Jean-Pierre Molenat ${ }^{24}$, por no incluir en el testamento a los hermanos del

17 ECHEVARRÍA ARSUAGA, A.: «De Cadí a alcalde mayor. La élite judicial mudéjar en el siglo XV (II)», en Al-qantara, revista de estudios árabes, XXIV, 2003.

$18 \mathrm{http}: / /$ maytediez.blogia.com/2005/060301-reales-cartas-ejecutorias-del-archivo-de-la-real-chanciIleria-de-valladolid.-fue.php\#ixzz22SP533Nr (fecha de consulta, julio de 2012).

19 El título CCLXXII de Las Leyes de Moros dice así: «Non herede el moro al christiano, nin el christiano al moro; et non se hereden los de dos leyes nada.»

20 ARChVa, RCE, 76-33.

21 ARChVa, RCE, Caja 150-38.

22 ARChVa, RCE, Caja 181-22.

23 ARChVa, RCE, Caja 99,13.

24 MOLENAT, J-P.: «Alfaquies anonymes dans la Castille des Rois Catholiques», en Biografías mudéjares o la experiencia de ser minoría: biografías islámicas en la España cristiana, Ana Echevarria Arsuaga, ed., Estudios Onomásticos-Biográficos de al-Andalus, XV, CSIC, Madrid, 2008. 
fallecido, «los quales, segund açuna e ley de moros, avian de entrar e heredar en la dicha parte» ${ }^{25}$.

\section{EL PLEITO POR ABDALLÁ DE SANTO TOMÉ}

De todos estos procesos destaca por su excepcionalidad el promovido por el padre de la nieta del rico tratante y mercader abulense Abdallá de Santo Tomé, fundamentando su demanda en la aplicación de la Sharia, o derecho musulmán, contra la viuda de Haçan de Santo Tomé, hermano y socio de Abdallá, a la que acusan de haber tomado buena parte de los bienes sin tener derecho a ellos; la reclamación se hace en primera instancia al alcalde de Ávila para, posteriormente, apelar a la Real Chancillería.

Esta excepcionalidad aludida del documento fue la que provocó nuestro interés por él, ya que permitía profundizar en el conocimiento de la familia mudéjar, además del juego que el comercio de ciertos productos destinados a las élites castellanas podría proporcionarnos. También resultaba atrayente por tratar aspectos relacionados con la organización familiar y por referirse a la pequeña localidad segoviana de Martín Muñoz de las Posadas - poco conocida en los estudios de la minoría-, situada actualmente en el límite con la provincia de Ávila y, en época medieval, frontera con la diócesis abulense.

Como hemos indicado, una de las cuestiones que nos llamaron la atención del pleito eran las concernientes a la organización familiar. En él, en algunas partes del documento, se podía deducir la posibilidad de la práctica de la poligamia de algún miembro de la familia de Santo Tomé al referirse a sus consortes, lo que quedó posteriormente descartado al aludir el término consorte —no al marido respecto de la mujer, y mujer respecto al marido- sino a las personas que litigan unidas, formando una sola parte del pleito ${ }^{26}$. De cualquier forma esto no restaba atractivo al documento ya que otras partes eran tan interesantes como ésta.

La segunda razón por la que estudiamos la ejecutoria, es debido a que alude al municipio de Martín Muñoz de las Posadas ${ }^{27}$, pequeña localidad situada al oeste de la provincia de Segovia, limítrofe con la de Ávila.

25 Ibídem, p. 433.

${ }^{26}$ La RAE define el término de la siguiente manera. Del lat. consors, -ortis, participante, y presenta tres acepciones: 1. com. Persona que es partícipe y compañera con otra u otras en la misma suerte. 2. com. Marido respecto de la mujer, y mujer respecto del marido. 3. com. pl. Der. Personas que litigan unidas, formando una sola parte en el pleito.

27 Martín Muñoz debe su homónimo, como otras muchas localidades de la zona, a su poblador, personaje que acompañó a Rodrigo Díaz de Vivar, del que era lugarteniente y familiar, por lo que le fue entregado este territorio. Martín Muñoz de las Posadas es un municipio de la provincia de Segovia, situado entre los ríos Voltoya y Adaja. En época medieval formaba parte de la diócesis segoviana y de la Comunidad de Ciudad y Tierra de Segovia, y, en la división de ésta, al sexmo de las Posaderas que 
Llama la atención que en la localidad además existiera una morería incluida en la relación de lugares del obispado de Segovia que aportaban impuestos directos a la corona castellana, y que en el reparto de 1491 tributara -para contribuir a los gastos de la guerra de Granada- 2.500 maravedís, los mismos que Pedraza y quinientos más que Cuéllar o Sepúlveda, morerías a priori más importantes:

[...] e de dicho rrepartymiento e seruiçio cupo a pagar a las dichas aljamas de los moros del obispado de Segovia las contyas de maravedis que adelante dira a las aljamas de los moros de los lugares siguientes:

A vos, las aljamas de los moros de la çibdad de Segovia, XXX M.

A vos, los moros de la villa de Cuellar, II M.

A vos, los moros de la villa de Sepulveda, II M.

A vos, los moros de la villa de Pedraza, II M D.

A vos, los moros de Martin Munnos de las Posadas, II M D.

A vos los moros de Guadarrama, V M.» 28

Este dato nos permite intuir la posible población mudéjar de la localidad, que no serían más de 506 familias que, multiplicadas por 5 miembros cada una, formarían una comunidad de 25 o 30 personas sobre un total de 453 vecinos $^{29}$, teniendo en cuenta que un castellano de oro tiene una equivalencia de 485 maravedís. Afirma Madoz que Martín Muñoz en el año 1858 tenía 258 vecinos distribuidos en 120 casas, lo que significaría que más o menos la mitad estarían cerradas. Los mudéjares de la ciudad de Segovia pagaban en este reparto 30.000 maravedís, lo que nos hace suponer una población de unas 60 o 65 familias o de unos 350 indi-

estaba formado por los municipios de Martín Muñoz de las Posadas, Aldea Vieja, Blascohelles, Muñoveros, La Cuesta, Aldehuela del Codonal y Domingo García. Administrativamente es dependiente de Segovia pero comercialmente lo es de Arévalo.

Sus orígenes conocidos los encontramos en el siglo XI, siendo escenario de continuos enfrentamientos bélicos entre cristianos y musulmanes por el control de la frontera, hasta la repoblación de Alfonso VI hacia 1088. Situada en un cruce de caminos entre Ávila, Madrid, y Valladolid, era parada de descanso de la corte y la población estaba obligada a acogerlos en sus casas y dar cobijo y alimento a nobles y caballerías, por lo que, según algunos autores, adoptó el apellido de «las Posadas».

28 AGS-RGS, 149103-53.

${ }^{29}$ El sexmo de Posaderas estaba muy poblado a finales del siglo XV y comienzos del XVI. En la descripción que se hace en 1533, se dice: «Por manera que el dicho sexmo de Posaderas hay seis lugares y en ellos mil noventa y ocho vecinos. Cúpoles a pagar de servicio el dicho año de 1528 doscientos veintiún mil trescientos maravedís, y por razón de la dicha vecindad y de las calidades de los dichos lugares y vecinos puesto que en Martín Muñoz de las Posadas y en Aldea Vieja hay algunos ricos y otros de medianas haciendas y que cogen mucho pan y vino parécenos que deben pagar ciento sesenta y cuatro mil maravedís", Juan de Figueroa y Jerónimo Solís: Parecer sobre la averiguación de las vecindades de la provincia de Segovia, 1533, Ed. La Hoja del Monte, 2006, p. 42. 
viduos, cifra coincidente con la propuesta por Ladero Quesada en su momento ${ }^{30}$ y por María Asenjo ${ }^{31}$.

Resulta también llamativo en este proceso que invocando a «la ley e açunna de moros» la parte litigante se utilice la justicia ordinaria cristiana y se apele a la Chancillería y no se acuda a la justicia islámica ${ }^{32}$ como parece lógico, al mantener la comunidad musulmana una judicatura propia a través del «alcalde mayor de los moros de las aljamas del reino» autorizado por nombramiento real $^{33}$. A su vez, este alcalde mayor nombraría a sus delegados o lugartenientes, equivalentes al na'ib qadi islámico ${ }^{34}$ como ha estudiado Ana Echevarria en su trabajo sobre el cadiazgo, que tendría competencia jurídica sobre su ciudad y su zona de influencia; además era autorizado por la corona y aceptado por el consejo de la aljama correspondiente. En ambos casos tenían capacidad para actuar «asy en los casos çeviles como en los criminales» y otorgar sentencia de acuerdo a su ley ${ }^{35}$. Más llamativo resulta todavía cuando uno de los alfa-

30 LADERO QUESADA, M. Á.: Los mudéjares de Castilla en tiempo de Isabel I, Instituto «Isabel la Católica», Valladolid, 1969, p. 17; del mismo autor: «Los Mudéjares en los reinos de la Corona de CastiIla: Estado actual de su estudio» en III ASIM, Teruel, 1984, pp. 5-20.

${ }^{31}$ ASENJO GONZÁLEZ, M.: Segovia. La Ciudad y su Tierra a fines del medievo, Diputación de Segovia, Segovia, 1986, p. 337 y ss.

32 La justicia musulmana es ejercida por la figura del alcalde mayor de las aljamas: «[...] es nuestra merçed e voluntad que agora e de aqui adelante para en toda vuestra vida seades nuestro Alcalde Mayor de todas las aljamas de los moros e moras de todas las çibdades, e villas, e logares, de los nuestros regnos e sennorios, e ayades e tengades el uso e execuçion del dicho ofiçio con la escrivania al dicho ofiçio.» AGS-RGS 147501-362, f. 1r. Según A. Echevarria Arsuaga, el alcalde de moros era «el encargado de administrar justicia, dictaminar sobre materia de fe y moral, decidir en disputas teológicas, supervisar el desarrollo de la vida de la comunidad, actuar como representante de la comunidad musulmana ante las autoridades cristianas y gestión de los bienes de viudas y huérfanos», pudiendo ser identificado con la figura del qadi al-qudat, principal personaje de la jerarquía judicial en el califato cordobés. Ver Echevarria Arsuaga, A.: «De Cadí a alcalde mayor. La élite judicial mudéjar en el siglo XV, en Al-qantara, revista de estudios árabes, XXIV, 2003. También Torres Fontes, J.: «El alcalde mayor de las aljamas de moros del reino de Castilla», en Anuario de Historia del Derecho Español, 1962. Molénat, J-P.: «À propos d'Abrahen Xarafi: les alcaldes mayores de los moros de Castilla au temps des Rois Catholiques», en VII ASIM, Teruel, 1999, pp. 175-184.

${ }^{33}$ La corona castellana autoriza tanto a los alcaldes mayores como a los alfaquíes a ejercer la justicia dentro de la comunidad mudéjar, al tener el Alcalde Mayor de moros la jurisdicción civil y criminal dentro de las aljamas y, por tanto, estar autorizado por la corona a dar sentencia de acuerdo con «la ley e açunna de moros». Lo vemos claramente en la carta de nombramiento de Abrahan Xarafi como alcalde mayor por parte de los Reyes Católicos: «[...] vos e los dichos vuestros logarestenientes por vuestra sentençia o sentençias segund ley e açuna de moros, e que la sentençia o sentençias que sobre ello dieredes e pronunçiaredes las llevedes e fagades llevar a efeto e debida esecuçion quanto e como devades, segund la dicha ley e açuna de moros [...]» AGS-RGS 147501-362, f. 1 r.

De cualquier forma también pueden los musulmanes acogerse a la justicia ordinaria cristiana para solucionar sus conflictos legales, ya que ésta, como hemos visto en líneas anteriores, es universal para todos los súbditos de la corona, incluidas, claro está, las minorías étnico-religiosas.

34 «[...] e ayades e tengades el uso e execuçion del dicho ofiçio con la escrivania al dicho ofiçio de Alcalde Mayor anexa e perteneçiente, e podades usar e usedes del dicho ofiçio de Alcaldia por vos e por vuestros logarestenientes [...]» AGS-RGS 147501-362, f. 1r.

35 En el nombramiento de Abraham Xarafi como Alcalde Mayor de las aljamas de moros de Castilla, el título queda definido de la siguiente manera: «E mandamos e defendemos que qualesquier jueses e justiçias de los dichos nuestros rregnos e sennorios de qualquier juridiçion que sean, que non conoscan nin entremetan de conosçer de pleitos algunos, ceviles nin criminales que tocaren de 
quíes de la ciudad de Ávila era familiar de uno de los denunciantes, concretamente de Gibe Calderero, se trataba del alfaquí del almagid de la Alquibla don Açeyte $^{36}$.

Esta postura únicamente puede explicarse en el contexto de preferencia por acudir a los tribunales y autoridades cristianas ${ }^{37}$, haciendo valer las mercedes otorgadas por la corona por las que se les permitía acudir a los alcaldes cristianos para evitar banderías y luchas internas. Las aljamas de Ávila y Segovia protagonizaron varios pleitos en este sentido y cuando Abrahan Xarafi reclamó el reconocimiento como Alcalde Mayor de las aljamas del reino de las alcaldías de Ávila, Toledo y Segovia para él y sus oficiales, éstas se mostraron contrarias a su nombramiento,

[...] que nos sabiamos que la dicha aljama e vesinos e moradores della, de diez, e veynte, e treynta, e quarenta e çinco annos e mas tienpo a esta parte, que syenpre la dicha aljama e vesinos e moradores della avian estado e estavan en paçifica posesyon de non tener nin obedecer alcalde ninguno mayor de las aljamas de Castilla salvo la nuestra justiçia hordinaria [...] e que el sennor rey don Enrrique, nuestro hermano que sancta gloria aya, seyendo ynformado que a cabsa de aver Alcalde Mayor de moros en la dicha aljama oviera en ella en los tienpos /f. $2 \mathrm{v} /$ pasados muy grandes diferencias e debates, e quistiones e muertes de onbres entre los moros della, de la qual cabsa fuera perdimiento de mas de treynta vesinos a la dicha aljama $[\ldots]^{38}$.

Este enfrentamiento traería graves consecuencias para la aljama segoviana, ya que piensan cuatro años más tarde que se elevó el reparto del servicio y medio

moro a moro de que a vos el dicho don Abrahan Xarafi, nuestro Alcalde Mayor, e a los dichos vuestros logarestenyentes pertenesca oyr e librar e determinar e conosçer, ca nos por la presente los ynibimos e avemos por ynibidos del conosçimiento e esecuçion de todo ello", (el subrayado es nuestro) AGSRGS, 147501-362, f. $1 \mathrm{v}$.

36 «...estando en la casa del almaxi del alquibla, estando ende los moros de la dicha moreria del alquibla en su yunta,... e estand ende don Aseyte su alfaqui,... », AHPAv Protocolos-420 f. 264r. Esta mezquita, identificada por Serafín de Tapia, estaría situada en el sur de la ciudad y «a la que acudirían los moros más ricos de la ciudad», según el mismo autor. Ver Tapia Sánchez, S.: La Comunidad Morisca de Ávila, Ed. Universidad de Salamanca, Salamanca, 1991.

$37 \mathrm{Si}$ bien el Ordenamiento de Valladolid sobre moros y judíos (1412) obligaba a los mudéjares a estar sujetos a la legislación cristiana, con el objetivo de dificultar al máximo la vida de las minorías religiosas y facilitar su conversión, en 1418 varía la política real de restricciones por otra más tolerante que generó, en opinión de Ana Echevarria, nuevas situaciones que condujo a muchos musulmanes preferir ser juzgados por el alcalde del concejo cristiano, que por el alcalde de la aljama, renunciando expresamente a su privilegio de tener jueces propios. Torres Fontes afirma que «los Reyes Católicos, al igual que sus antecesores, no respetaron sus propias disposiciones ni las atribuciones concedidas a estos alcaldes mayores». La aljama de Segovia los expresa de la siguiente forma: «porque de tienpo ynmemorial a esta parte ellos avian seydo e heran subjetos [los moros] solamente a los justiçias de la dicha çibdad de Segovia, e non al dicho parte adversa nin a otro Alcalde Mayor», ARChVa, RCE, Caja 39-06. La aljama abulense también protesta, ordenando a su corregidor que prohíba a Xarafi y a sus lugartenientes el ejercicio de sus cargos y que averigüe cómo anteriormente se ejercía la jurisdicción civil entre los moros de Ávila, AGS-RGS, 149603-41.

38 ARChVa, RCE, 39-06, ed. Echevarria Arsuaga, A.: «Las aljamas mudéjares castellanas en el siglo XV: redes de poder y conflictos internos», en Espacio, Tiempo y Forma, Serie III, t. 14, 2001, pp. 93-112. 
servicio que les correspondía más de un $80 \%$, pasando de contribuir con 3.000 maravedís anuales a 5.500 en 1494, y así se lo trasladaron a los reyes para buscar su amparo. Refiriéndose a Xarafi, dicen que «les tiene odio e enemistad a cabsa que non le quisieron rreçibir por alcalde mayor en la dicha aljama, por cavsa que de una carta que de nos tenian» ${ }^{39}$.

En 1490, la misma aljama segoviana acusa de los disturbios que padeció la aljama a la presencia de alcalde, justificando de ese modo el no reconocimiento a maestre Lope y a Xarafi como alcaldes mayores:

[...] que de çinquenta annos a esta parte ellos nunca han tenydo nin rresçibido allcalde moro en la dicha aljama fasta oy, porque diz que a cabsa de aver allcalde moro en la dicha moreria a auydo grandes escandalos e rreuelos e muertes de onbres, de manera que se an perdido mas de treynta et cinco casas de moros et se despoblo la dicha moreria de los mas prinçipales moros della $[\ldots]^{40}$

Efectivamente, en 1480, cuando quiso ocupar la alcaldía el maestre Lope ${ }^{41}$, Segovia se defendía de la misma manera, evitando reconocer al alcalde mayor:

[...] La qual, la dicha aljama de los dichos moros, diz que le non quisieron rresçibir por allcalde, [...] diziendo e alegando que en vida del rrey don Enrrique, non tovieron allcalde mayor, e asy mesmo diziendo e alegando otras escusas e dilaçiones yndevidas por donde non la devian conplir. [...]

Los reyes fallarían en este caso a favor de maestre Lope «reciban e ayan e tengan al dicho Maestre Lope por allcalde mayor de las aljamas de los moros de los dichos nuestros regnos, e usen con el en el dicho ofiçio segund que en la dicha nuestra carta de merçed se contiene».

Otros casos similares ocurren en otras aljamas castellanas como Plasencia, donde se prohíbe a Hazys Bejarano usar el oficio de alcaldía de moros hasta tanto no se resuelva un pleito que tiene pendiente ${ }^{42}$; en Aranda, el alcalde del aljama de moros es acusado «diziendo que en todos los pleitos e cabsas suyos que ante vos pasan diz que les soys muy odioso e sospechoso ${ }^{43}$ ", por lo que no es de extrañar el recelo de la comunidad mudéjar para ser juzgada por sus alcaldes.

Aunque el pleito que estudiamos se trata en 1492, el conflicto familiar por el reparto de los bienes de los Santo Tomé se inicia con anterioridad. Como vemos en el árbol familiar (ver anexo 2), Mahomad de Santo Tomé tuvo cuatro hijos, habiendo fallecido ya el segundo de ellos ${ }^{44}$, Hamad, antes de febrero de 1487. En

\footnotetext{
39 AGS-RGS, 149409-151.

40 AGS-RGS, 149008-82, los subrayados son nuestros.

41 AGS-RGS, 148002-259.

42 AGS-RGS, 149302-20.

43 AGS-RGS, 149302-20.

44 Se mantiene el patrón onomástico de nombrar al hijo primogénito con el nombre de su abuelo, vemos como en este caso ambos hermanos utilizan Mahomad; el segundo hijo varón toma el nombre
} 
esta fecha Xanci ${ }^{45}$ (I) otorgó un poder a su hermano Abdallá para el cobro de la parte que a ella la correspondía por la muerte de su hermano y que tenía Haçan ${ }^{46}$. De modo que, aunque el pleito quedara cerrado en su momento, la herida no debió cicatrizar y cinco años más tarde se vuelve a abrir entre los herederos, en este caso de Abdallá.

\section{El proceso}

El pleito se inicia con la presentación de la demanda de una de las partes, a quien representaba un procurador ante la audiencia para, una vez admitida la misma, ser notificada a la otra parte,

Sepades que plito paso e se trato en la nuestra corte e chancelleria ante el nuestro presidente e oydores della entre Duenna, fija de Fatima (I), mora, e de Abdalla de Santo Tome, e Gibre Calderero, en su nonbre como su tutor, e Gomar Perexil, en nonbre e como legitimo administrador de Fatima III, su fija, nietos del dicho Abdalla de Santo Tome, e Muharrache del Camino, e Farax de las Navas, vesinos de la çibdad de Avila e sus procuradores, acusadores de la una parte, /f. 1v/ e Fatima II, muger de Aça de Santo Tome e sus fijos, vesinos del lugar de Martin Munnoz de las Posadas, tierra de Segovia e su procurador en su nonbre de la otra $[\ldots]$

Aunque el documento trata diferentes temas, en este trabajo, nos centraremos en dos cuestiones. Una es la ejecutoria y sentencia del pleito litigado por Dueña, hija de los fallecidos Fátima I y Abdallá de Santo Tomé, junto con Gibre Calderero, Gomar de Perejil, Muharrache del Camino y Farax de las Navas, contra Fátima II, la viuda de Haçan de Santo Tomé — hermano y socio de Abdallá- vecina de Martín Muñoz de las Posadas (Segovia), acusada por los primeros de apropiarse de parte de la herencia que les correspondía. La segunda la dedicaremos a las actividades comerciales de los Santo Tomé ${ }^{47}$ y a su expansión fuera del territorio de la corona de Castilla.

del padre. En el caso de las mujeres ¿Ocurriría esto mismo?, parece que no ya que Fátima III no utiliza el nombre de su abuela Xanci.

45 Ya que algunos nombres se repiten generacionalmente, utilizaremos los numerales romanos para poder distinguir a las diferentes personas al dirigirnos a ellas.

46 «En Ávila, sábado dies e siete dias de dicho febrero, yo donna Xançi, hija de don Mahomad de Santo Tome, conosco que do poder a vos Abdalla de Santo Tome, mi hermano, para que por mi e en mi nonbre podays aver e cobrar de Haçan de Santo Tome, nuestro hermano, vesino de Ávila, la parte que me pertesçio e pertenesçia aver e heredar de Hamad, nuestro hermano e de otra qualquier cosa quel me deua dar e pagar. E para dar carta de pago e sustituyr todo a nuestro cargo otorgo carta fyrme. Testigos: Alafe, moro, e Juan de Hermosa, e Pedro de Espinosa, vecinos de Ávila.» AHPAv, Protocolo 420, f. 263 r.

47 Sobre las actividades económicas, tanto de los Santo Tomé como de otros comerciantes, el Archivo Provincial de Ávila nos proporciona abundante documentación, especialmente los Libros de Protocolos 420, 421 y 460. 
La causa sigue fielmente la estructura de este tipo de pleitos. Se inicia en primera instancia en Ávila, ante Cristóbal de Benavente, alcalde de la ciudad ${ }^{48}$, al que presentan los demandantes una relación de hechos ${ }^{49}$ y las correspondientes pruebas y a quien solicitan, como juez ordinario y competente en la administración de justicia ${ }^{50}$, que reparta los bienes entre los herederos ${ }^{51}$, para continuar en grado de apelación en la Chancillería ${ }^{52}$ al presentar el procurador de Fátima II, el cristiano Andrés de Valladolid, el correspondiente recurso ante ese estamento, teniendo así dos partes bien diferenciadas: las iniciadas en Ávila a petición de Giber y la apelación, presentada en segunda instancia en la Chancillería por Fátima II.

Respecto a la demanda en primera instancia presentada en Ávila, los demandantes describen los hechos afirmando que: «antes que falleciese (Haçan), tomara muchos bienes muebles e rrayses e semovientes del dicho Abdallá de Santo Tome, su hermano, e que agora los tenýa e poseýa Fatima II», pidiendo al alcalde que, al estar los bienes en la ciudad de Ávila, obligara a comparecer a Fátima II como si estuviera en la ciudad para:

[...] ver faser la dicha petiçión e diuisyón en los dichos bienes que ansy auian seydo del dicho Abdallá de Santo Tomé e de la dicha su muger, antellos e an[te]

48 «El qual dicho plito preuiamente se començo en la cibdad de Avila, antel bachiller Christoval de Benavente, alcalde en la dicha çibdad de Avila, e vino a la dicha nuestra corte e chançelleria en grado de apelaçion, suplicaçion, nulidad o agravio...». ARChVa, RCE, 46-23, f.1r.

49 «[...] quel dicho Abdalla de Santo Tome e la dicha Fatima II, su muger, falleçieron desta presente vida e que todos los susodichos suçedieran en çierta parte e en çierta forma, segund ley e açuna de moros, e que asy mismo avia sucedido Haçan de Santo Tome, su hermano. E que despues que falleçiera, el dicho Açan, e antes que falleciese, tomara muchos bienes muebles e rrayses e semovientes del dicho Abdalla de Santo Tome, su hermano, e que agora los tenya e poseýa Fatima II, su muger, vesyna que avia seydo (sobreescrito: a la sason) de la dicha çibdad de Avila, e que el dicho Abdalla de Santo Tome dexara otros bienes muebles e rrayses e semovientes, los quales todos los dichos herederos los tenyan e poseyan proyndeviso e por partir. E que por quanto non quieran mas estar en dominio, salvo que cada una de las partes conosçiese lo suyo, segund e por la forma que su ley e açunna /fol $2 \mathrm{r} / \mathrm{de}$ moros se devia dividir e partir [...]» ARChVa, RCE, 46-23, f.1v-2r.

50 Alcalde es una locución proveniente del árabe: al-cadi, que significa «juez». Su origen se encuentra en el siglo XI, en el fuero de León dictado por Alfonso V en 1020, cuando las asambleas vecinales que administraban justicia ven la necesidad de contar con jueces permanentes nombrados por el rey. Esta designación se hacía a todos los funcionarios investidos de atribuciones judiciales, estando vinculado a los jueces elegidos en el Concejo municipal, para compartir con el iudex, presidente de la asamblea, de acuerdo a la tradición visigoda, la función judicial. Con el paso del tiempo, a éstas tareas judiciales se le irán añadiendo las administrativas.

Alfonso X define el cargo de juez ordinario en la Ley I del Título IV de la Partida III, diciendo «...otros jueces hi ha que son puestos en logares señalados, asi como en las çibdades o en las villas, o allí do conviene que se juzguen los pleitos: et aun otros hi ha que son puestos por todos los menestrales de cada logar o por la mayor partida dellos, et estos han de poder juzgar los pleitos que acescen entre si por razon de sus menesteres. Et todos estos juezes que habemos dicho llamanlos en latin ordinarios."

$51 \mathrm{E}$ pidieron al dicho alcalde que partiese los dichos bienes [que] estauan en la dicha çibdad...

52 «El qual dicho plito preuiamente se començó en la cibdad de Ávila, antel bachiller Çhristoval de Benavente, alcalde en la dicha çibdad de Ávila, e vino a la dicha nuestra corte e chançelleria en grado de apelaçión, suplicaçión, nulidad o agravio» ARChVa, RCE, 46-23, f.1v. 
cada uno dellos, e a dar cuenta e rrasón personalmente, e non por procurador, de todos los bienes que auia tomado el dicho su marido $[\ldots]^{53}$

Recordemos que Fátima II vivía en Martin Muñoz de las Posadas, aldea de la tierra de la ciudad de Segovia, por lo que la petición de los demandantes plantea un conflicto de jurisdicciones entre el alcalde de Ávila y el corregidor de Segovia. Por haberse trasladado de Ávila a esa localidad, los demandantes piden al alcalde que embargue los bienes que Fatima II tenía en la ciudad, a lo que el alcalde accede embargando y precintando la vivienda de la viuda:

[...] el dicho alcalde mandó dar e dio su mandamiento para que los dichos Alí de las Navas e Gomar Perexil pudiesen echar e echasen un candado con su llave a las puertas de las casas de la dicha Fátima II, [...] E ansy mismo mandara enbargar todos e qualesquier bienes que la dicha Fátima II tuviese en la dicha çibdad de Ávila e su tierra [...]

Anteriormente, la parte litigante, apremia al alcalde para que dé cuenta de los bienes que Fátima II había tomado de su marido, afirmado que ella «avia huydo e absentado de la dicha çibdad de Ávila contra la voluntad de los suso dichos herederos", alegando que:

[...] los dichos bienes eran en la dicha çibdad de Ávila, e que como quier que ella estava en el lugar de Martín Munnoz de las Posadas, que era tenuda e obligada de venir personalmente a faser la dicha divisyón e partiçión, del dicho rrequerimiento que fasian al dicho alcalde pidieron la partiçión, e ansy mismo pidieron al dicho alcalde que por quanto la dicha Fátima non absentase los bienes que tenía en la dicha çibdad ge los mandase enbargar, fasta tanto que diese fianças de estar antellos a derecho $[\ldots]$

El alcalde abulense se equivoca al actuar así ya que las partidas alfonsinas amparan a la viuda y en la Partida III, Título III, Ley IV se dice: «Responder non debe en juicio el demandado ante otro alcalle sinon ante aquel que es puesto para judgar la tierra do el mora cotidianamente». Por lo tanto, corresponde a Fátima II declarar ante el corregidor segoviano y no al de Ávila, por tener que hacerlo en el término de su jurisdicción por ser la acusada, como bien dice Juan de la Plaza, su procurador ante la justicia de Ávila,

E Juan de la Plaza, en nonbre y como procurador de la dicha Fátima II, paresçiera antel dicho alcalde e presentara un escripto de rrazones [...], por quanto la dicha Fátima II hera vezina e domiçiliaria en la çibdad de Segovia, e su juridiçión e tierra [...] era rrea ante el dicho alcalde porque el abtor debýa seguyr el fuero del rreo, lo otro porque do esto çesase dixo que por ser la dicha su parte rrea devýa ser rremediada a su juridyçión a la çibdad de Segovia, donde avía corregidor e all-

${ }^{53}$ ARChVa, RCE, 46-23, f.2r. 
caldes que libravan plitos por nos donde la dicha su parte (Fátima II) estava presta de estar a justiçia con las dichas partes adversas ${ }^{54}$.

La postura y defensa de Fátima II es evidente porque además, como viuda, asume la titularidad del cabeza de familia con lo que ello llevaba implícito de responsabilidad familiar, conservación y administración del patrimonio ${ }^{55}$, más aún en este caso porque era «heredera e tenedora de los bienes de sus fijos " ${ }^{56}$ menores de edad, por lo que la respuesta es contundente:

[...] dixo que la dicha partiçión non pudiera nin deviera ser demandada... e que sy algo la dicha su parte oviera e tenia, dixo que serýa solamente lo que hera suyo della e a ella le pertenesçian, segund ley e açuna de moros, de lo que ella e su marido tenýan de manera que nin con demanda nin en demanda, nin debysyón, nin partiçión, nin abýa de que byenes se hiziese con ella. E que los dichos partes adversas llevaban camino herrado e que non sabian lo que pedian $[\ldots]^{57}$

Tras las correspondientes alegaciones, comparecencias y presentación de testigos ante el alcalde, éste da el pleito por concluido y Fátima II, ejerciendo nuevamente su derecho, apela ante el presidente y oidores de la Chancillería alegando que el alcalde de Ávila le denegó la ampliación de plazo para probar que: «ella non podýa ser heredera de su marido Açan de Santo Tomé porque avýa dexado hijos legítimos y herederos, los quales eran Mahomad, e Yuçafe, e Açan e Reyna [...] e que e que sy algo la dicha su parte oviera e tenia, dixo que seria solamente lo que hera suyo della e a ella le pertenesçian, "segund ley e açuna de moros"»58 para lo que alega que «hera muger, onesta e biuda e ynorante de los derechos» 59 .

54 ARChVa, RCE, 46-23, f.2v.

55 RODRÍGUEZ GONZÁLEZ, M. C.: «La mujer medieval en la familia campesina berciana», en ADAXE, 8, 1992, pp. 195-202.

56 ARChVa, RCE, 46-23, f.6r.

57 ARChVa, RCE, 46-23, f.6r.

58 ARChVa, RCE, 46-23, f. 3r. Posiblemente se refiera Fátima II a los bienes aportados al matrimonio por medio de su dote. En la tradición malikí impera la separación de bienes haciendo a la mujer independiente económicamente de su marido: «los hombres... deben dar parte de su riqueza a sus esposas, mientras que las mujeres no tienen el mismo deber hacia sus esposos o familiares» (Sura IV, 38), a excepción de las propiedades conjuntas que suelen corresponder a bienes raíces. Quizá la razón por la que Fátima II se instale en la localidad segoviana pueda estar relacionada con esto, con que tuviera alguna propiedad de su dote, o con que algún familiar viviera allí, al descartar que vivera alguno de sus cuatro hijos al ser menores como hemos visto.

59 Por lo tanto no estaba informada ni tenía alfaquí o lugarteniente o delegado del alcalde mayor de moros para que pudiera explicarla sus derechos de acuerdo a la sunna. Recordemos que una de las atribuciones del cargo de alcalde de moros es el control de los bienes de viudas y huérfanos, como identifica Ana Echevarria en su artículo «De cadí a alcalde...». En el caso de Fátima II el cargo de alcaldía de moros de Castilla correspondía a Abrahan Xarafi, quien interpone un pleito a la aljama segoviana por no reconocer su autoridad: «Don Fernando e donna Ysabel, etc. A vos el aljama de los moros de la çibdad de Segovia, salud e gracia. Sabedes conmo plito se trabto antel presydente e oydores de la nuestra abdiençia entre vosotros, de la una parte, e don Abrahen Xarafi, alcalde mayor de las aljamas de los moros de nuestros rreynos de la otra, sobre rrason que vosotros non quesystes obedesçer al dicho don Abrahen Xarafi por vuestro Alcalde desa dicha aljama.» AGS-RGS 149204294. De todos modos maestre Lope debía ser su lugarteniente en Segovia y a él se refiere otro docu- 
La otra parte, en buena lógica, solicita la confirmación de la sentencia pronunciada por el alcalde de Ávila, comenzando, de este modo, nuevamente la petición y aportación de pruebas; añadiendo Fátima II que los bienes de Abdallá los tenían la parte contraria ${ }^{60}$, fallando el tribunal que debían ambas partes aportar las pruebas que alegaban ante el tribunal para «ver e examinar los testigos e prouanças por su parte presentados en el pleito" e iniciar las pesquisas y resolver de manera definitiva el pleito. Para ello manda que «fisiesen juramento en su ley [...] E Gomar Perexil, e otros sus consortes a una, juraron en forma deuida, segund su ley ${ }^{61}$ y declarasen los bienes que cada uno tenía del difunto Abdallá ${ }^{62}$, como afirmaba Fátima II que tenían.

Así lo hacen todos, facilitando cada uno de ellos en su declaración un inventario de los bienes «que cada uno dellos tenya e poseyan, e avian deydo a su poder». En esta relación de bienes se mencionan ajuares y menaje doméstico, que no difieren mucho de otros inventarios de élites cristianas. De este modo podemos establecer comparaciones entre grupos, al ayudarnos a establecer el nivel de las distintas fortunas y a comprender la mentalidad y los gustos de las élites económicas urbanas. De manera general, como afirma M. C. Quintanilla Raso, podemos decir que el testamento es la expresión propagandística del poder del testador,

mento algo anterior en estos términos «que proueymos de dicho ofiçio a maestre Lope e a maestre Farax, moros vesinos de la villa de Madrid», AGS-RGS 149008-82. Por lo que vemos, la intervención del alcalde en Segovia queda muy limitada por la negativa de la aljama y sobre ello volveremos más adelante.

60 "que todos los bienes que auian sydo e fasido de Abdalla de Santo Tome, los tenian e poseyan los dichos partes adversas syn tener cosa alguna la dicha su parte».

${ }^{61}$ Los moros juraban según la shari'a, según las fuentes reales de derecho, siendo utilizada la misma fórmula en todos los tribunales, tanto castellanos como aragoneses. Aunque no figura en el documento se debió tomar de la siguiente forma: "Otrosy los moros han su jura apartadamente que deven faser en esta guisa: deven yr tanbien el que ha de jurar como el que debe faser la jura a la puerta de la mesquita sy la y oviere, synon en el lugar dol mandare el jurador; e el moro que oviere de jurar debe estar de pie e torrnarse de cara e alçar las manos contra el medio dia al que llaman ellos alquibla.

Et aquel que debe tomar la jura debe de desir estas palabras: "Jurasme tu fulano moro por aquel Dios que non ha otro synon el, aquel que es demandador e començador e destroydor e alcançador de todas las cosas e crio aquesta parte de quibla contra que tu fases oraçion, e otrosy jurasme por lo que rreçibio Jacob de la fe de Dios para sy e para sus fijos, e por el omenaje que fiso de la guardar, e por la verdat que tu tienes que puso Dios en la boca de Mahomad fijo de Abdalla, quando lo fiso su Profeta e su mandadero, segund que tu crees, que esto que esto que yo digo non es verdat, o que es asy como tu dises; et si mentira juras, que seas apartado de todos sus bienes de Dios e de Mahommad aquel que tu dises que fue su Profeta e su mandadero, e que non ayas y parte con el nin con los otros profetas en ninguno de los paraysos, mas todas las penas que dis el Alcorán que dara Dios a los que non creen en la tu ley vengan sobre ty."

Et a esto todo lo sobredicho, debe rresponder el moro que jura: "Asy lo juro".

Et disiendo todas estas palabras el mismo asy como las dixiere aquel que toma la jura desde el comienço hasta el cabo, e sobre todo esto desir amén.» Agradezco a Ana Echevarria esta información.

62 «declarasen todos ellos que bienes tenyan e poseyan e avian venydo a su poder de los bienes que auian seydo e fincado de Abdalla de Santo Tome, ya defunto» ARChVa, RCE, 46-23, f.8r. 
donde quedan reflejadas sus posesiones y la última voluntad del destino de sus bienes ${ }^{63}$.

En este caso, al ser una confesión personal, el inventario es un tanto anárquico al no incluir una descripción organizada de los bienes. Únicamente podemos hacernos una idea del patrimonio de Abdallá gracias a las declaraciones que realizan los intervinientes, donde exponen aquellos que habían recibido y a la relación que sobre el menaje doméstico hiciera el propio Abdallá y que estaba en poder de Gomar Perejil.

Aunque la descripción es muy sumaria y apenas indica nada sobre las características o el valor de los bienes enumerados, nos ayuda a comprender aspectos relacionados con la vida cotidiana, la materialización del consumo y los hábitos de su rango social: jubones, telas, lienzos, arcas, platos valencianos, espadas, lana... Un arca con escrituras y, según Farax de las Navas, «nin dineros, nin oro nin plata ${ }^{64}$.

\section{La sentencia}

Parece oportuno aclarar la situación general del proceso, y del estado de las cosas antes de leer la sentencia dictada por la audiencia. En primer lugar, Haçan de Santo Tomé fallece antes que su hermano Abdallá, por lo que su viuda e hijos son sus herederos y Abdallá no heredaría nada ${ }^{65}$ : «y no hereda ningún heredero, sin haber librado ${ }^{66}$ lo que dejó de las dejas ${ }^{67}$ derechoreras ${ }^{68}$ en el testamento; ni heredan sin pagar primero las debdas que debiere el muerto de sus algos ${ }^{69}$ ». De nuevo las palabras de Fátima II se fortalecen, al no poder heredar porque su marido Açan de Santo Tomé había dejado hijos herederos (Mahoma, e Yuça, e Açan, e Rreyna), pero como vemos le correspondería 1/8 de los bienes de su marido ${ }^{70}$, a sus hijos varones 2/8 a cada uno y a su hija Reyna 1/8, cumpliéndose de este modo la Azora IV, versículo 12: «Debdeció (por obligó) Alá, en vuestros hijos, que

${ }^{63}$ QUINTANILLA RASO, M. C.: «La nobleza», en Orígenes de la monarquía hispánica: propaganda y legitimación (ca. 1400-1520), coord. por José Manuel Nieto Soria, Ed. Dykinson, Madrid, 1999 pp. 98-100.

${ }^{64}$ ARChVa, RCE, 46-23, ff. 8v a $11 \mathrm{r}$.

65 «Los hermanos de padre y madre heredan todo el algo, cuando no habrán otros herederos más prençipales; y asimesmo un hermano, todo el algo, cuando fuera solo en la herencia», en Sánchez Pérez, J.: Partición de herencias entre los musulmanes del rito maliquí: con transcripción anotada de dos manuscritos aljamiados, Ed. Centro de Estudios Históricos, Madrid, 1914.

66 Entregado, pagado, satisfecho.

67 Legados.

68 Legítimos.

69 Corán: Azora IV, versículo 13.

70 «Lo de auer la muger de su marido, synon dexare fijo, nin fijo de fijo della o de otra: el quarto. Et sy dexare fijo o fija de fija della, o de otra que aya, el ochavo.» Leyes de Moros, Título CCXCIII. Edición de Pascual de Gayangos. 
hereda el varón dellos semejante parte que dos henbras», presente en el derecho malikí.

Respecto a los bienes de Abdallá, los hijos de Açan son herederos de su tío, como dicta el juez en su sentencia, fallando que los bienes de Abdallá de Santo Tomé «se partiesen e dividiesen, "segund ley e azuna de moros", en esta gysa» ${ }^{71}$.

De esta forma todos los bienes de Abdallá son presentados ante el tribunal para poder efectuar el reparto de acuerdo a «ley e açuna de moros», incluida la parte que Abdallá hubiera heredado de sus viudas (1/2 de los bienes de cada una de ellas) ${ }^{72}$.

A Fátima II la correspondería una parte de la herencia, como dice el juez, «en nonbre de los dichos sus hijos e de Açan de Santo Tome, su marido, oviese e heredase la una parte dellos» ${ }^{73}$ por ser menores, como hemos visto anteriormente, porque «Cuando el difunto dexara menores de edad, el juez debe allegar sus parientes del difunto y de los guerfanos y aber su ynformacion de quien los deba tener; y si ay madre o aguela por parte de madre, darle an la tenecia dellos y de sus bienes $[\ldots]^{74}$. El resto de bienes se repartiría entre los nietos de Abdallá: «e que todos los otros byenes oviesen e heredasen todos los nietos e herederos del dicho Abdalla de Santo Tome», es decir Dueña, su hija, Fátima III, su nieta ${ }^{75}$, y su

71 «Que la dicha Fatima II, en nonbre de los dichos sus hijos e de Açan de Santo Tome, su marido, oviese e heredase la una parte dellos, e que todos los otros byenes oviesen e heredasen todos los nietos e herederos del dicho Abdalla de Santo Tome.

E que todos los bienes que avyan seydo e fyncado de Xançi II, muger que fue de Abdalla de Santo Tome, e ella dexara al tienpo de su fyn y muerte, mandaron que los oviese y heredase Farax de las Navas, su hermano y heredero. E que mandaron que todos los dichos byenes fuesen traydos a partiçion e colaçion, e se partiesen ygualmente segund de susodicho es por todos los susodichos, tomando una parte de los dichos byenes los hijos del dicho Açan de Santo Tome /fol 14v/ e la dicha Fatima II, en su nonbre, segund la dicha ley e Açuna de moros.

E que los otros byenes los oviesen todos los otros susodichos herederos que para faser la dicha diuision e partiçion que cada uno de los susodichos traxesen a colaçion e partiçion todos los bienes que cada uno dellos tenya e vinyera a su poder de los bienes que avian seydo e fincado de los dichos Abdalla de Santo Tome e Fatima I, su muger.

72 «Cuando moriere una muger e dexa marido o madre e hermano, ha de auer el marido la meytad de todo el algo, et la madre el sexmo, e el hermano lo otro. Ase de faser el algo seys partes: lleua el marido las tres, e el hermano las dos, e la madre la una.» Leyes de Moros, Título CCXXXIX. Edición de Pascual de Gayangos.

73 Ley de Moros, Título CCLXXXVIII, de los herederos de los onmes que son diez: «Los herederos de los onmes son diez: el fijo, el fijo del fijo; e el padre, e el abuelo. Et el hermano, e el fijo del hermano. Et el hami, e el fijo del hami, e el marido e el sennor. Et los herederos de las mugeres son syete: las fijas e la fija del fijo quando el açediese, e la madre e la abuela, e la hermana, e la muger e la sennora». En el Breviario sunní, capítulo 45, de las Herencias y tutorías, dice que «los herederos de los varones son veynte: el hijo y el hijo del hijo, y los que allí deçendieren, y el padre y el aguelo y quantos de alli binieren semejantes al aguelo de parte de padre, y el hermano de padre, y el hijo de hermano de padre y madre y de allí arriba, y el tio de padre y ay arriba, y el tio del padre de padre y madre (hami), y el hijo del tio del padre de padre y madre y de ay arriba, y el propinco en deudo de parte de padre, aunque sea apartado, quando no ubiere otro mas cercano, y el marido; y el señor es heredero en falta de heredero legitimo. Los tres que no cesan en ningún tiempo son: el padre, el hijo y el marido.

74 Breviario sunní, capítulo 45, de las Herencias...

75 Estos son únicamente los herederos directos localizados y que aparecen en el documento, aunque no debemos descartar que hubiera alguno más. 
hermana Xançi I si viviera, a quienes corresponderían a cada una de las hijas la mitad al varón, y las hermanas se repartirían el tercio de los bienes entre las que hubiere ${ }^{76}$ :

Pero, ¿qué ocurriría si no hubiera herederos? En caso de que no existieran sucesores el derecho malikí indica que «la casa del algo ${ }^{77}$ hereda todo el algo, en falta de herederos», es decir, que pasarían a la comunidad musulmana, a la aljama local según «ley e açuna de moros», aunque los Reyes Católicos establecen en 1489 que estos bienes pasen a la «camara e fisco ${ }^{78}$ »:

[...] ayays vuestra ynformaçion e que moros son los que asy son muertos sin dexar los dichos herederos e en cuyo poder quedaron los dichos bienes e que personas son los que los tienen et por que titulos et escrituras. Et la ynformaçion avida e la verdad sabida, escrito en lynpio et çerrada e sellada, en manera que faga fe, la enbiedes ante Nos al nuestro consejo, para que en el se vea e se prouea sobrello lo que fuere justicia $[\ldots]^{79}$

El juez, además, condenó a levantar el embargo que hizo el alcalde de Ávila, Cristóbal de Benavente, tanto de los bienes de Fátima II como de sus hijos ${ }^{80}$, sancionando al pago de las costas —incluidas las de esa audiencia- a los acusadores, siendo notificada al procurador de Gomar y sus consortes, Francisco de Valladolid. Fátima II acepta la sentencia aunque dice que «en termino en que debyera suplicar hera ya pasado, e non avya suplicado de la dicha sentençia, e que hera ya pasada en cosa juzgada» 81 .

\section{EL COMERCIO CON VALENCIA}

Otro aspecto de sumo interés para el conocimiento de la sociedad mudéjar nos lo reporta la segunda parte de la descripción de las propiedades del difunto Abdallá, donde, después de describir los bienes propios de un ajuar doméstico,

76 Sobre otros repartos musulmanes ver Zomeño Rodríguez, A.: «Documentos árabes y biografías mudéjares", en Biografías mudéjares o la experiencia de ser minoría: biografías islámicas en la España cristiana, ed. Ana Echevarria Arsuaga, Estudios onomástico-biográficos de al-Andalus, XV, CSIC, 2008.

77 La casa del algo es el tesoro de la comunidad musulmana, en Sánchez Pérez, J.: Partición de herencias entre...

${ }^{78}$ La reina Isabel de Castilla reclama para la corona las herencias de moros que no dejaran herederos, encomendando que se hicieran las averiguaciones correspondientes de qué personas tienen sus bienes: «que en la çibdad de Avila e su tierra son muertos de poco tienpo aca muchos moros e moras syn dexar fijos nin fijas, nin nietos deçendientes de varon [...]" AGS,RGS, 148906-178; "son muertos muchos moros et syn dexar lyguitimos herederos nin parientes que heredasen sus bienes. Por lo qual los dichos sus bienes perteneçen a Nos e a nuestra camara e fisco, e que algunas personas se an entrado en los dichos sus bienes» AGS-RGS, 148903-120.

79 AGS-RGS, 148903-120, f. $1 \mathrm{r}$.

80 «E alçaron qualquier embargo que obiese seydo puesto por lo suso dicho, e qualesquier byenes de la dicha Fatima e de los dichos sus hijos.» ARChVa, RCE, 46-23, f. 14v.

${ }^{81}$ ARChVa, RCE, 46-23, f. 15r. 
detalla los bienes y valores de la compañía «de rrenta e trato» que Abdallá tenía con su difunto hermano y en la que también participaba Gomar Perejil:

[...] Estos byenes suso dichos dixo el dicho Gomar Peregil, que tiene porque están secrestados ${ }^{82}$ en su poder, segúnd que dicho tiene [...] e ansý mismo dixo que /fol $12 \mathrm{r} /$ él e el dicho Abdallá de Santo Tomé tenýan conpannia de rrenta e trato, $[\ldots]$

Por el contenido del documento podemos suponer que los Santo Tomé eran una rica familia dedicada al comercio, perteneciente a la élite urbana e integrada en la ciudad, junto con otras familias como los Caro o los hermanos Almirante, que mantenían unas prósperas relaciones que se extendían hacia el reino de Valencia $^{83}$ y otras importantes ciudades de la corona de Castilla como Plasencia. Del negocio formaban parte Abdallá y Açan de Santo Tomé y Gomar Perejil, yerno de Abdallá ${ }^{4}$ y padre de Fátima III, dedicando su actividad a la compra-venta de ganado para ser utilizado en la arriería, «de bestias çerriles, asy mulares conmo rroçiniegas e asnales a vender de una parte a otra ${ }^{85}$ », al comercio-transporte de mercancías y al préstamo dinerario.

Lógicamente, la declaración más reveladora al respecto será la de Gomar. Además, de ella se deduce que Abdallá había fallecido de manera repentina, cuando regresaba de Valencia:

[...] que cuando el dicho Abdalla murio el estaua en Valençia con çierta mercaduria del dicho trato, [...] E quando vino a esta çibdad, fallo que el dicho Abdalla hera muerto, $[\ldots]^{86}$

Pero volviendo a los distintos bienes y valores de la compañía, encontramos que uno de los principales debió de ser el de la cría y venta de mulos, según se desprende de las fuentes, entre ellas el propio pleito: «que tenía [...] una muleta e ocho yeguas, e un muleto que ovo de las dichas yeguas $[\ldots]^{87}$.

En los libros de Protocolos de Ávila encontramos también algunos contratos sobre un negocio que debía reportar buenos ingresos, ya que estos animales eran esenciales para el trasporte de todo tipo de productos por su resistencia y capacidad de carga:

\footnotetext{
82 Embargados.

83 Las actividades comerciales de mudéjares castellanos con Valencia debieron ser muy numerosas y desarrolladas por varias familias. Este aspecto, aunque de manera breve, fue tratado por Serafín de Tapia y pude ayudar a comprender la presencia de objetos y vajillas valencianas de tipo andalusí en muchos ajuares de Ávila, Arévalo, etc. Tapia Sánchez, S.: La Comunidad Morisca de Ávila, Ed. Universidad de Salamanca, Salamanca, 1991.

84 Gomar es yerno de Abdallá por estar casado con su hija Haxa, fruto del primer matrimonio del mercader con Xançi II (ver árbol genealógico).

${ }^{85}$ AGS-RGS, 148809-24.

86 ARChVa, RCE, 46-23, f. 12r.

87 Ídem, f. 11v.
} 
En Ávila, viernes treynta dias del dicho março [1487], yo Juan de la Yglesia, fijo de Juan Martin, debdor; e Juan de Miguell Heles, fijo de Miguell Rrodrigues, vesino de Collado de Moranna, aldea de Avila; de mancomun conosçemos que deuemos al dicho Abdalla quatro mill e çiento e çinquenta maravedis de un mulo $[\ldots]^{88}$

En 1488, un vecino de Fuentes de Año reconoce que mantiene una deuda con el maestre Abdallá por la compra de un mulo ${ }^{89}$. En marzo del mismo año un vecino de Villanueva del Aceral también reconoce adeudar a Abdallá 5.200 maravedís por una mula, en este caso, «ensillada e enfrenada» 90.

Pero, en buena lógica, también otros moros de Ávila se dedicaban a este beneficioso negocio, entre otros, Aseyte «el Gallo» o Brayme Retaco. Igualmente también participaban en él cristianos como, por ejemplo, Pedro López de Robles que vende a Çaçeme unos potros, Gonzalo de Ribilla, Diego Martín, vecino de El Campillo, o Antón Maroto que vende a Huzmel y Mahomad un asno por 500 maravedís. Como advertimos a través de estas escrituras notariales no se trata ésta de una actividad propia de la minoría, aunque, como afirma Serafín de Tapia, pudieran tener cierta especialización ${ }^{91}$. Las mulas descansaban y estaban guardadas en los prados de Piedrahita y Valdeprados donde debían de ser cuidadas por un guarda ${ }^{92}$. Probablemente la actividad económica de la venta de caballería fuera derivada de la propia cría y, por lo tanto, complementaria de la principal que sería el comercio con Valencia.

En ese comercio de los Santo Tomé con la ciudad levantina, la información que nos suministra el documento es de gran relevancia debido a que mueven importantes sumas de dinero en las distintas transacciones. A modo de ejemplo, las mercancías que traía Gomar Perejíl de Valencia, cuando fallece Abdallá, calcula Gomar que tendrían «un valor de unos 40.000 mrs, mil más o mil menos», y continúa diciendo:

[...] que ansy mismo tenia este dicho Gomar, en Plazençia, çierta mercaderia de la dicha conpannia lo fue a vender e con ello e con çierto lienço rraval, [...] que lo vendio e pudo hazer hasta veynte mill maravedis del dicho lienço [...] e que se debya en la dicha Valençia de la dicha conpannya ochenta e dos mill e quinientos maravedis de çierto pape ${ }^{93}$ que avya traydo de un genoves e que ansy de la dicha mercaderia que traxo de Valençia puede valer quarenta mill maravedis, mill mas o mill menos, como los dichos veynte mill maravedis, todo lo puso a la dicha çibdad $[\ldots]^{94}$

\footnotetext{
88 AHPAv, Protocolos, 420, f. 268r.

89 «Miguell Sanches del Axo, vesino de Fuentes de Anno, aldea de Avila, debdor, e Juan Rresto, vesino de San Juan de la Torre, fiador, de mancomun conosçemos que deuemos al dicho maestre Abdalla [de Santo Tomé] quatro mill e dosientos maravedis de un mulo». AHPAv, Protocolos, 420, f. 300v.

90 Ídem, f. 302 v.

91 de Tapia Sánchez, S.: La Comunidad morisca de Ávila, Salamanca, 1991, p. 71.

92 Valdeprados, o Val de Prados, es un lugar de Aldea del Rey Niño, a unos $10 \mathrm{~km}$. de la ciudad de Ávila, donde, dice Madoz, «hay una pequeña casa para habitación del "guarda". El terreno es de tercera calidad, y en su mayor parte de monte de encina y pastos.»

93 Quizá se refiera a letras de cambio.

94 ARChVa, RCE, 46-23, f. 12r.
} 
No cabe duda de que estas cifras son realmente significativas, máxime si las comparamos con las ganancias de trabajadores cualificados como pude ser un oficial carpintero ${ }^{95}$, que ganaba en Ávila 25 maravedís al día, es decir, unos 625 $\mathrm{mrs}$ al mes o $7.500 \mathrm{mrs}$ anuales. Lo que manifiesta que estas mercancías estaban destinadas a las élites abulenses, como medio de expresión del poder social y civil de quien los portara, independientemente de su adscripción religiosa. Los préstamos y las inversiones en este tipo de negocio garantizaban su éxito ya que, por ejemplo, un judeoconverso acuerda adelantar a mercaderes moros unas cantidades que varían entre los 56.000 y los 15.000 maravedís en diferentes ocasiones, concretando que sean en «mercadurias de Valençia» ${ }^{96}$. No es de extrañar por tanto, que otro mercader moro solicitara amparo real para ir a Valencia y Aragón:

Don Fernando, etc. Al mi justiçia mayor e a sus logarestenientes [...] Sepades que Çayde, moro vesino de Avila, me fizo relaçion por su petiçion que ante mi en el mi consejo presento disyendo que el va a tratar sus mercaderias al rreyno de Valençia, e rreyno de Aragon e condado de (en blanco) e a otras partes de mis rreynos e sennorios. $E$ que se teme e rreçela que algunos caualleros o otras personas lo querran mandar ferir o lisiar, prender o enbargar, o faser otro mal o danno e desaguisado alguno en su persona e bienes contra rrason e derecho [...] e pidio por merçed que le proueyese de rremedio con justiçia mandadole dar una carta de seguro o conmo la mi merçed fuese. Et yo tovelo por bien, $[\ldots]^{97}$

En opinión de Serafín de Tapia, el negocio textil estaba muy vinculado a los mudéjares durante todo el siglo $X^{98}$, por lo que parece lógico pensar que las «mercaderías» que llevaban a Valencia fueran textiles que allí intercambiaban o vendían. La imagen económica de los musulmanes abulenses es por tanto mucho más rica y diversa, dado que el comercio de los ricos tejidos italianos parece que era monopolio mudéjar como consecuencia de las relaciones con los estados mediterráneos a través de Valencia.

Las relaciones de castellanos con mercaderes italianos está documentada desde fecha temprana, de las que ya se hacían eco las Cantigas al relatar las visitas de estos italianos a la Virgen de la Arrixaca ${ }^{99}$; en las tierras murcianas está probada la actividad en un privilegio de Fernando III de 1251, lo que parece indicar una presencia anterior y el mantenimiento de un próspero comercio, en este caso, con los musulmanes murcianos ${ }^{100}$. Carmen Carlé profundiza en ello y nos

\footnotetext{
95 AHPAv, Protocolos, 421 f. 217v.

96 TAPIA SÁNCHEZ, S. de,: «Fiscalidad y actividades económicas de los mudéjares en Ávila», en III ASIM, Teruel, 1992, pp. 87-104.

97 AGS-RGS, $14907-463$ f. $1 \mathrm{r}$.

98 TAPIA SÁNCHEZ, S. de,: «Fiscalidad y actividades...

99 TORRES FONTES, J.: «Genoveses en Murcia (siglo XV)», en Miscelánea Medieval Murciana, II, 1976, p. 73.

100 MOLINA MOLINA, A. L.: «Proyección mediterránea en el reino de Murcia en la Edad Media», en Miscelánea Medieval Murciana, XVII, 1992, pp. 59-75.
} 
habla de la presencia de estos mercaderes genoveses ${ }^{101}$ en Murcia y Cartagena: «donde se avecindaron o formaron compañías con los vecinos para, aprovechando las franquicias de éstos, no pagar almojarifazgo » 102.

J. Hinojosa Monsalvo, en su estudio sobre el comercio exterior valenciano durante el siglo XIV afirma que la realidad cotidiana se circunscribe a la exportación de unas cuantas mercancías: pez, sebo, velas, alquitrán, metales, derivados de la madera, etc., situándose a la cabeza de ellos la pez ${ }^{103}$. A estos productos se añadirían diversas manufacturas típicamente valencianas como la cerámica, el papel o el hilo de seda. A Valencia llegaban por estas fechas paños de Perpiñan, apareciendo los artículos italianos hacia 1378, quedando implantado, continua el mismo autor, «el tráfico comercial y financiero con Italia, en el que la lana y la seda, los tejidos italianos y los tintes crearon un fuerte entramado de intereses que benefició a Valencia y a sus mercaderes, activos partícipes en estas empresas ${ }^{104}$ ", siguiendo una tradición que se remonta a la época musulmana con un comercio controlado por italianos y basado en el comercio de esclavos, en la exportación de cereales y en la importación de paños, creando de esta manera una comunidad de intereses entre Valencia, las repúblicas mercantiles italianas y los reinos peninsulares.

Hacia mediados del siglo XV los genoveses iniciaron el estímulo empresarial y técnico en torno a la seda. En 1479 la documentación oficial recoge la presencia de 200 tornos de seda y de 172 telares de terciopelos, satenes y damascos, con un colectivo de unos trescientos ligures especializados ${ }^{105}$.

Aunque este ámbito temático ha sido menos estudiado en comparación con otros, bien relacionados con aspectos institucionales, o sobre cuestiones fiscales, por lo que apreciamos, las actividades económicas, y en especial el comercio con la ciudad mediterránea debieron ser muy prósperos, ocupando a un buen número de mudéjares castellanos ${ }^{106}$. Además, las mercancías traídas desde allí debieron ser muy valoradas por la sociedad, como demuestra que

\footnotetext{
101 Aunque la documentación nos ofrece información sobre algunos comerciantes lombardos y milaneses, la inmensa mayoría de las noticias que tenemos sobre la actividad de los comerciantes italianos se refiere a los procedentes de Génova, como también pasaba en la vecina Valencia. Véase Hinojosa Montalvo, J.: «Mercaderes en la Valencia del siglo XV», en Saitabi, XXVI, 1976, pp. 4-5.

102 CARLÉ, M. C.: «Mercaderes en Castilla (1252-1512)», en Cuadernos de Historia de España, XXIXXII, 1954, p. 231.

103 HINOJOSA MONTALVO, J.: «Aspectos del comercio exterior valenciano en el siglo XIV (13511378)», en Anales de la Universidad de Alicante. Historia Medieval, 1999, pp. 207-236.

104 Ibídem.

105 NAVARRO ESPINACH, G.: «La seda entre Génova, Valencia y Granada en época de los Reyes Católicos", en Actas del Congreso la Frontera Oriental Nazarí como Sujeto Histórico (S.XIII-XVI), Almería, 1994 , pp. 477-484.

106 Otra familia también dedicada al comercio era la arevalense Medino que solicita «la provixión de los reyes para que no le cobren impuesto de paso por las ciudades, villas y lugares del marquesado de Villena y del obispado de Cuenca». RGS, 148809, 24.
} 
incluso existieran zonas exclusivas para la venta de productos llegados desde Valencia ${ }^{107}$.

Como ya hemos visto por la declaración de Gomar Perejil, los Santo Tomé mantenían negocios con Génova, o al menos con genoveses, citando la compra de papel valorado en 82.500 maravedís: «çierto papel que avya traydo de un genoves» 108 .

La del papel era una industria que adquiere, desde mediados del siglo XV, un fuerte protagonismo debido al invento de la imprenta. A partir de entonces tendrá una fuerte demanda, haciendo necesaria la obtención de esa manufactura con mayor rapidez y abundancia, modificando las reglas de fabricación establecidas por la tradición heredada de los papeleros hispanoárabes. Las técnicas de elaboración serían mejoradas, a partir del siglo XIII, por los artesanos genoveses al aplicar en su fabricación avances técnicos que dieron lugar a la producción del «papel de Génova» y a la construcción de máquinas específicas protegidas por una abundante legislación ${ }^{109}$. Respecto a la posibilidad de referirse Gomar a «letras de cambio», las necesidades de financiación de las empresas italianas obligaron a poner un sistema de intercambio eficaz, debido a tres elementos fundamentales. Primero, las propias necesidades de financiación; segundo, el papel que jugaban las élites mercantiles establecidas en Valencia; y tercero, y más importante, ofrecer los medios adecuados a los mercaderes para transferir grandes sumas de capital de un lugar a otro con relativa celeridad y seguridad y para anticipar dinero o suministrar a la corte víveres, tejidos y cualquier tipo de mercancía incluido el material bélico ${ }^{110}$.

De cualquier forma, las relaciones entre la Corona de Aragón y el Señorío de Génova fueron «tradicionalmente hostiles» ${ }^{111}$, lo que no fue obstáculo para que los genoveses, a finales del siglo $\mathrm{XV}$, se mostrasen en el reino valenciano más prósperos que nunca. Lo que viene a probar el interés con que en los reinos peninsulares se acogía la actividad italiana en general, y genovesa en particular, como provisora de artículos interesantes y fuente permanente de ingresos para el erario público.

107 En el encabezado del documento se lee: «Almuzara, Casa de los toros, al canton donde se venden las mercaderias de Valençia.» A.P.Sg D.H. 24-13.

108 No sabemos con certeza si se referirá a letras de cambio o a papel de imprenta, de cualquier modo el valor del mismo es muy elevado. ARChVa, RCE, 46-23, f.12r.

109 HIDALGO BRINQUIS, M. a C.: «La fabricación del papel en España e Hispanoámerica en el siglo XVII», en V Jornadas científicas sobre documentación de Castilla e Indias en el siglo XVII, organizadas por el Departamento de Ciencias y Técnicas Historiográficas de la facultad de Geografía e Historia de la Universidad Complutense de Madrid, 2006, pp. 207-223.

110 IGUAL LUIS, D.: «Entre Valencia y Nápoles. Banca y hombres de negocios desde el reinado de Alfonso el Magnánimo», en En la España Medieval, N. 24, 2001, pp. 103-143.

111 HINOJOSA MONTALVO, J.: «Mercaderes extrapeninsulares en la Valencia del siglo XV», en Saitabi, XXVI, 1976, p. 63. 
Por lo tanto, advertimos que las actividades mercantiles de los mudéjares abulenses no se limitaban a comerciar con productos como especias, aceite, higos o lana, sino que también lo hacían con artículos de lujo, debiendo tener un protagonismo importante en la entrada y difusión del «papel genovés» en Castilla durante el último cuarto del siglo XV, sin olvidar su actividad como prestamistas o la cría y venta de caballerías. En definitiva, estaban presentes en todas las actividades ciudadanas y en una gran variedad de sectores.

\section{CONCLUSIONES}

Aunque los datos aportados son modestos, creemos que pueden contribuir a mejorar el conocimiento sobre la minoría mudéjar de la corona castellana, apoyándonos en el ámbito familiar y comercial de una de ellas, estudiado, en este caso, a través de un pleito. Su lectura pausada nos ha obligado a detenernos y llamar la atención sobre algunos aspectos, a nuestro parecer, reveladores para desmontar el discurso de la irrelevancia de esta «minoría marginada».

Por un lado, respecto a la familia, vemos como la sociedad musulmana tenía una concepción familiar que abarcaba a un gran número de miembros, constituyéndose en una unidad económica. En la misma el padre se erigía en la figura de jefe, y a él se sometían todos los integrantes de la familia. Esta configuración familiar, aunque suavizada por la doctrina maliquí, seguirá conservando la estructura familiar y la supremacía del varón de la etapa precedente. En este caso Abdallá de Santo Tomé es la cabeza que ejerce de manera clara ese rol, el vínculo fundamental de la sociedad familiar basada en la colaboración y en la parentela, es decir, en los vínculos de interés común ${ }^{112}$.

En segundo lugar, la aplicación por parte de la justicia cristiana de la «ley e açuna de moros" demandada por una parte de los litigantes en el caso del reparto de la herencia de un miembro de la comunidad, parte central del estudio, derivando hacia el conocimiento del porqué de la desconfianza de una parte de la comunidad mudéjar en la aplicación de su ley por sus propios jueces.

En tercer lugar, podemos añadir una localidad más al mapa mudéjar, teniéndola así en cuenta para otros estudios que sobre la zona se puedan llevar a cabo en el futuro, junto con las aljamas de la ciudad de Segovia, Cuéllar, Sepúlveda, Pedraza, Guadarrama y Real de Manzanares. Martín Muñoz es un enclave privilegiado por su situación entre Ávila, Segovia y Valladolid y que, según cuenta la tradición debió existir algún asentamiento árabe primitivo dedicado al cultivo de la huerta y de la ganadería. De cualquier forma, es preciso profundizar la investigación en la zona, ya que nos puede reportar una valiosa información sobre la comunidad mudéjar. Es también interesante la opinión de Pablo Ortego, que considera

112 MAÍllo SALGADO, F.: Vocabulario de historia árabe e islámica, ed. Akal, 2.ㄹ ed., Madrid, 1999. 
que fue una aljama que perdió población entre fines del XIV y comienzos del XV ${ }^{113}$; la migración, posiblemente, les llevara hacia Madrid donde abundan los apellidos con ese topónimo.

Por último, la importancia de las actividades económicas impulsadas y desarrolladas por los mudéjares abulenses con la zona mediterránea, estando presentes en muchas de las actividades ciudadanas en donde se atisbara la posibilidad de negocio, y en sectores tan variados que oscilaban desde la artesanía textil, tanto en el comercio como en el monopolio de los tintes, a la introducción como hemos visto del preciado «papel genovés» en el corazón de Castilla, o las vajillas doradas valencianas, además de los objetos de lujo y ricos tejidos destinados a las élites castellanas.

${ }^{113}$ La migración se debió producir a partir de mediados del siglo XVI, ya que una población de 453 vecinos es muy numerosa en esta zona. 


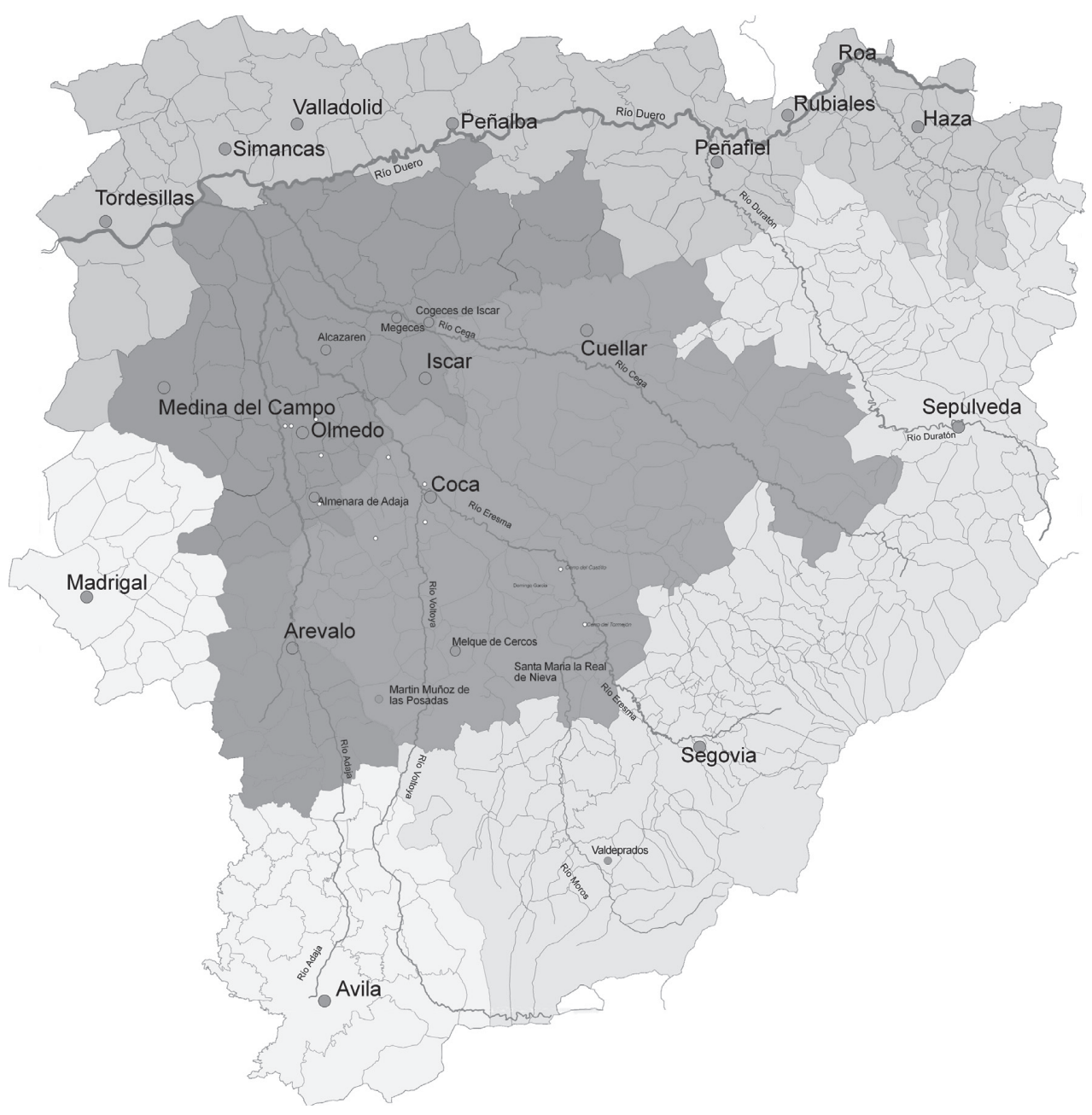

Anexo 1: mapa de la zona 


\section{LA FAMILIA SANTO TOMÉ}
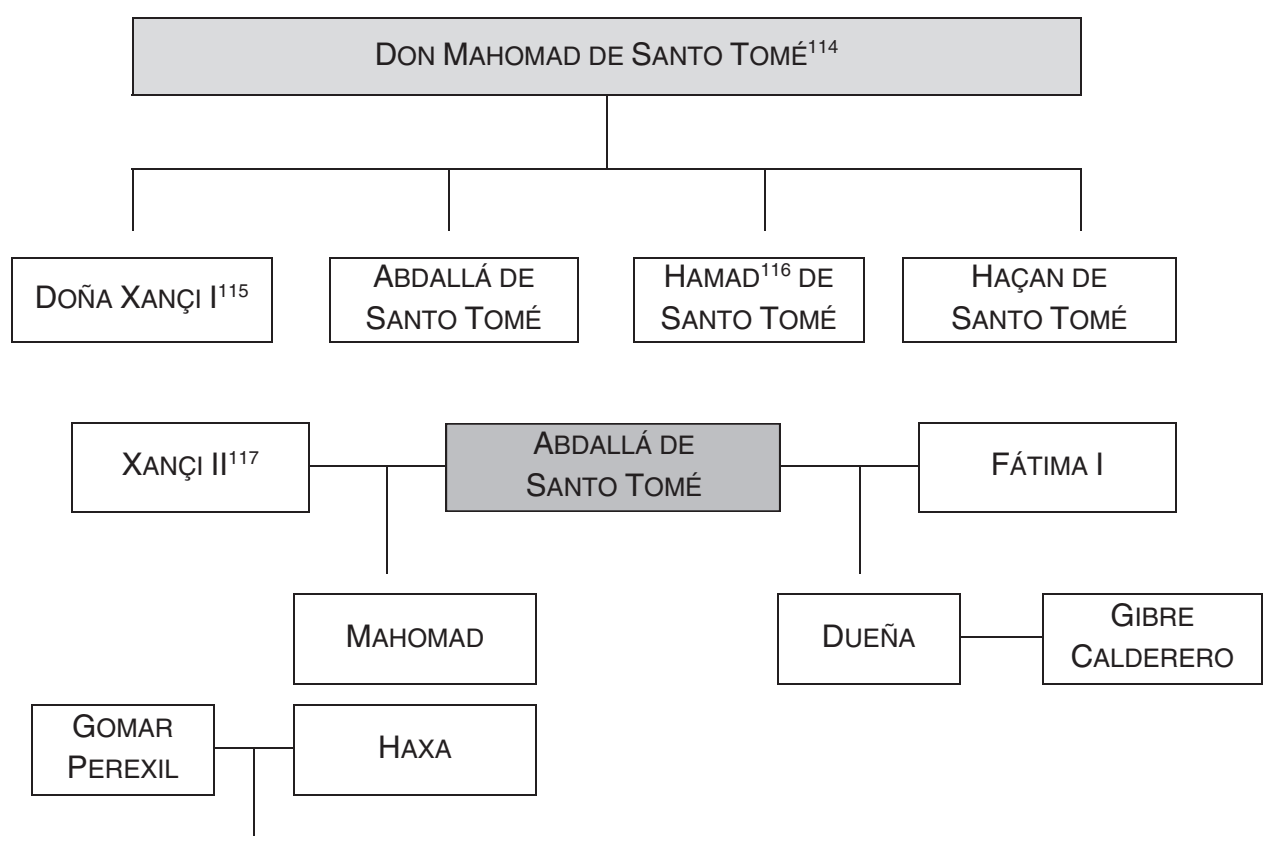

FÁTIMA III

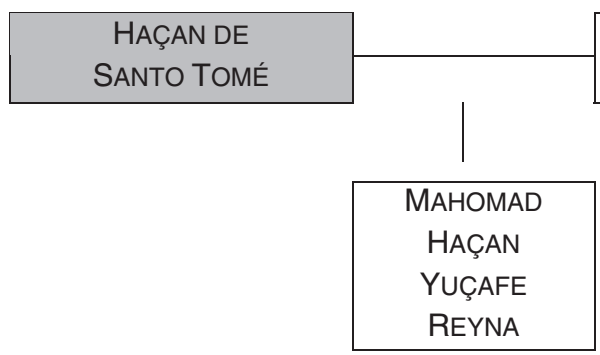

FÁTIMA II

Anexo 2: árbol genealógico de la familia Santo Tomé

114 AHPAv, Protocolo 420, f. 263r.

115 AHPAv, Protocolo 420, f. 263r.

116 AHPAv, Protocolo 420, f. 263r.

117 ARChVa, RCE, 46-23, f. 9v: refiriéndose a la declaración de Farax de las Navas, «[...] e a ellos le pertenesçian por fyn de Xançi su hermana, muger que fue del dicho maestre Abdalla [...]», y f. 14r: «E que todos los bienes que avyan seydo e fyncado de Xançi, muger que fue de Abdalla de Santo Tome, e ella dexara al tienpo de su fyn e muerte [...]». 